\title{
The History Education and Establishment of Multicultural Awareness of Students
}

\author{
Laili Masithoh Hamdiyah $^{1 *}$; Sutrisno Mohamad ${ }^{2}$; Mursalat Kulap ${ }^{1}$ \\ ${ }^{1}$ Faculty of Teacher Training and Education, Sebelas Maret University, Indonesia \\ ${ }^{2}$ Faculty of Social Science, Gorontalo State University, Indonesia \\ Email: lailimasithohhamdiyah@gmail.com
}

http://dx.doi.org/10.18415/ijmmu.v4i5.91

\begin{abstract}
This paper aims to analyze how the role of historical education in the establishment of multicultural awareness of students. The research used literature study method. The sources collected were then analyzed. The results show that historical education as one of the important instruments in the nation character building, has a strategic role in shaping multicultural awareness of students. Multicultural awareness referred to in this research is the awareness and recognition about the existence of ethnic, cultural, and so on, so as to strengthen tolerance in the life of the nation and state. Student multicultural awareness is formed from the understanding of past events that have multicultural values. The events referred to existed during the period of the national movement, for in that period the Indonesian nation discovered the concept of national integration and recognition of diversity.
\end{abstract}

Keywords: Historical education; Multicultural consciousness; Students

\section{Introduction}

The problem of multiculturalism awareness in the social interaction process of society is the most fundamental thing in Indonesia today. The more and more massive fundamentalist political movements, even it tends to lead to radicalism, become part of the problem of the Indonesian nation that must be resolved soon. Though finding a consensus as the foundation of the nation and state in the midst of the phenomenon of diversity, is not an easy thing. If viewed from a historical perspective, the process of forming consciousness as a nation that has a common vision of seizing independence, until the consolidation of social and political forces, has been done by the freedom fighters of Indonesia to realize the ideals of a just, prosperous, and based on the interests of humanity.

Recently, the multicultural phenomenon of Indonesian life in the diversity frame is being tested. Differences in political views and choices have succeeded in dominating, so acceptance of diversity becomes difficult, even the majority makes the existence of the group as a commodity in identity politics. Not only that, social conflicts stemming from certain ethnic, religious, and group disparities continue to occur even though the state is often present as a symbol of peace. The awareness of multiculturalism of the Indonesian nation is still at the level of superficial and cosmetic relations, or in the Stanley Fish terminology (in Sham, 2009) known as Bouitique Multiculturalism. It means that the consciousness of 
multiculturalism in Indonesia is partially - if it is not said entirely - still on the outer layer, not touched deep awareness yet. Thus, multicultural awareness of Indonesian society needs to be reconstructed to minimize the erosion of religious values in society that can threaten the integration of the nation.

One of the ways to create a multicultural awareness that gives hope in the future is the world of education. Freire (1985) said that education is a container of the formation of human consciousness, or better known as the process of humanization. Thus, the awareness of multiculturalism can be established through education. One part of education that has competence in the formation of multicultural awareness is historical education. According to Kochhar (2008), history provided learning about morality. History not only gives meaning to great moral qualities, heroism, self-sacrifice and so on, but also gives exemplary space of all these meanings to the students.

According to Kartodirdjo (1987), history is a structure of consciousness. It means that history is a consciousness of the past that is actualized to the present situation or future projection. History is seen as a structure of historical consciousness. There is continuity in the meaning of an event. Thus, history can serve as an instrument for the formation of multicultural awareness of past events. In a historical perspective, there is a periodization that describes an event or social reality about the formation of the consciousness of multiculturalism, namely in the period of the national movement where diverse ethnic elements form a wider consciousness and have have freedom ideals from Dutch colonial practice at that time. Genealogical and cultural disparities are not seen as destructive, but are seen as a force against the practice of colonialism. Multicultural awareness like this is what must be re-formed to the students as the next generation of nation, even actualized in life of nation and state.

In this study, the multiculturalism awareness is the awareness to accept and recognize ethnic, cultural, religious, and even political differences in the life of the nation and state. Heywood (2013) said that the consciousness of multiculturalism refers to the cultural diversity that arises from the presence of two or more groups within a society, and then forms a sense of collective identity that is different. The community groups have an attitude of tolerance and mutual recognition of the existence of one group and others even such recognition is very important.

Based on the description of the problems above, this study intends to provide a description of the analysis of how the role of history education in the effort of establishing multicultural awareness on students as the next generation of the nation.

This research used literature research method. According to Suwandi et.al (2016), literature research is a method of research by conducting studies on books, literature, notes, and reports relating to problems to be solved in research. Related to this research, the literature used is of course related to the education of history and its relation with the formation of multicultural awareness to the students. The data analysis developed in this study uses historical analysis to determine the relation of an event to the present state, and also the basis of consideration in making a decision.

\section{Potency of History in Education}

Based on the construction of Croce's point of view, nowadays is a continuity of the past. There is no reality in the present without the past. In other words, the concept of history according to Croce is the eternal concept of present reality. In a practical perspective, it can be said that to know precisely about the present, one must be able to recognize precisely the problems of the past. Furthermore, Croce also said that the historical facts to be explored must have meaning. That way, an event unrelated to contemporary life cannot be said to have historical value (Croce in Maarif, 2003). Thus, learning an event in the past is intended for the formation of the awareness of the values contained in the event. 
In addition to considering the aspect of past events, history also takes into account historical facts. All events in the past must be really or at least close to a historical fact. Collingwood (1969), said that historical facts are not a perception, but are derived from data. History must be understood from within and not enough to understand from outside events. Furthermore, Walsh (1960) said that as a science, history has the object of research that is about experience and human behavior in the past. Based on the above opinion, it can be said that history should be exploring historical facts about human experiences and activities in the past. In order to learn about the human past, the essential instrument is through historical education.

History education is a process to transfer knowledge about past events to students with the aim of the formation of historical awareness as the foundation of interaction in life in the present. Kartodirdjo (2005) said that in addition to providing factual knowledge, historical education also provides awareness. It means that historical education evokes historical sense and opens historical optics, or historical contextual thinking. Furthermore, Soedjatmoko (1976) said that historical consciousness demands the awareness of identity as a nation in the present era. Joebagio (2015) also said that the deepening of historical events will result in the exemplification of wisdom and the wisdom that resulted from the process of historical education.

Aman (2011) added that historical consciousness is part of the socio-cultural function of history lessons. This can inspire the young generation in forming and strengthening the nation's character. History also reveals the development of multiethnic, legal systems, languages, kinship systems, beliefs, and so on. Thus historical consciousness is an important part in the effort to project the present and the future.

Learning history is not something without function. According to Kartodirdjo (1992), people who do not know history, it will look like a madman because he does not know his identity. If that happens, it will be very dangerous to people's lives. The past crisis can trigger behavior that is not in accordance with the norms or values of life prevailing in society.

Based on the opinions of some experts mentioned above, it can be said that history has strong potential as a consideration and guidance in living life in the present and future. By studying history in the world of education, is expected to form a historical awareness of students and then guide their behavior patterns. Through internalization of the values contained in history, students are expected to actualize it. Then what values can be internalized and actualized in by the students in everyday life? The answer to that question depends on what material will be presented in history learning classroom, and from which perspective we look at a historical event.

In relation to this research, one of the values that can be derived from a historical event is about multicultural awareness. Then what events can be presented and can shape the multicultural awareness of the students? One of them is related to the struggle to seize independence in the period of national movement. In addition to the values of nationalism, Indonesia's history of the national movement can internalize the values of multicultural based on events that occurred at that time. To be more specific, it will be described in the next chapter on the relation between historical education and the formation of multicultural awareness to students.

\section{Relation of Historical Education and Multicultural Awareness}


As described above, history has the potential as a guide in thinking and acting the present generation in everyday life. Hasan (2012) said that history education plays a role in character formation. This is because history has a strategic meaning in the formation of character as a dignified nation and the formation of Indonesian people who have a sense of nationality and love of the homeland. Character formation that is said by hasan is religious, honest, tolerant, disciplined, hard work, creative, independent, democratic, curiosity, spirit of nationality, love of the homeland, appreciation of achievement, friendship / communicative, love of peace, care about the environment, social care, and responsibility.

From the characters described by Hasan, there are characters that represent multicultural awareness, such as tolerance, democracy, friendship, peace of mind, and social care. This shows clearly how the relation of historical education with the formation of multicultural awareness. According to Hannam (1971), one of the expected goals of teaching history is the formation of awareness to understand and appreciate the mutual existence of one nation with other nations. If this hope materializes, then the events that claimed many victims like World War I and World War II will never happen. This view strengthens the relation between historical education and the formation of multicultural awareness among students.

Related to multicultural awareness, Blum (in Ujan et.al, 2011) said that multicultural awareness is an awareness to understand, appreciate and curiosity about other people's culture. Multiculturalism is seen as a way of looking at how indigenous cultures are able to express value to their own members. Multiculturalism is not a perspective that seeks to shape the equality of local truths, but rather tries to help different parties to build mutual respect for the differences and plurality that exist between one another.

Then how the historical education role in shaping the multicultural awareness. As explained earlier that history is able to form a person's or group's consciousness with the formation of historical consciousness through past experiences. This means that one way is to explore historical events that contain the values of multicultural awareness. For example, at the end of the second decade of the early twentieth century, precisely in 1928, youth from diverse ethnic, religious and other backgrounds managed to establish tolerance between them in order to strengthen resistance to the Dutch government. Not only that, at the beginning of $20^{\text {th }}$ century Netherland had established an organization of youth associations of Indonesia who studied in the Netherlands, namely PERHIMPUNAN INDONESIA. This organization consists of youths with different ethnic and religious backgrounds. Some of them came from Java Island, those originating from the island of Sumatra. The organization has succeeded in formulating its political manifesto by Kartodirdjo (2005) as a symbol of the development of the Indonesian nationalist movement. This is what this generation needs to emulate. Thus, through such an understanding of history, it is hoped that the students' historical awareness will be established and will continue to create multicultural awareness in daily life.

Beside the positive side of historical education in an effort to integrate the diversity of nations as described above, Zuhdi (2014) also described how the negative side of historical education must be anticipated in the social life that could threaten the integration of the nation. The first factor is the existence of ethnocentrism point of view that showed controversy or even conflict between ethnic one with other in the past. For example: between Sundanese and Javanese in the case of Gadjah Mada figures and many other examples. The second factor is the assumption of the elements of history of the past by just continuing in the present. If the events of the conflict in the kingdoms were interpreted the same as Indonesia in the present era, then conflict would be easy. The history of Indonesia as a country should be viewed as a consensus to achieve a justice and prosperity that was begun in the early 20th century as the starting point of a national struggle.

In an effort to address and avoid the negative side effects of history in education, preferably in the transfer of historical material to students, teachers should consider national interests above the interests of 
the group. By not ignoring the element of historical facts, teachers must present a historical lesson that is capable of shaping the multicultural awareness of students for the sake of the nation future.

\section{Conclusion}

Based on the result of the research described above, there are two things that can be concluded: the first, history has the potential in education to form human consciousness. Such awareness depends on historical events to be described in historical education. Through learning history in schools, students are expected to internalize and actualize the historical values derived from the knowledge and understanding of history in depth. Learning of history will guide students in a wiser direction and can emulate the wisdom of the individual behavior as well as the group of historical actors. In short, history is able to have a profound effect on current codes of conduct, including how social interactions are in the midst of a multicultural society.

The Second, in relation to the formation of multicultural awareness, historical education must be able to provide presentation and deepening of historical material that has a correlation with multicultural values. Student multicultural awareness is formed from the understanding of past events that have multicultural values. The events referred to existed in the period of the national movement, for in that period the Indonesian nation discovered the concept of national integration and recognition of diversity. Thus, the implementation of historical education in schools should be further optimized by considering the formation of multicultural awareness to strengthen the integration of Indonesian nation diverse.

\section{References}

Aman. (2011). Model Evaluasi Pembelajaran Sejarah, Yogyakarta: Ombak.

Collingwood, R.G. (1969). Human Nature and Human History, in Nash, Ronald H (ed). Ideas of History, Volume I : The Critical Philosophyof History, New York : E.P. Dutton \& Co., Inc.

Freire, Paulo. (1985). Pendidikan Kaum Tertindas, Jakarta : LP3ES.

Hannam, Charles L. (1971). Prejudice and the Teaching of History, in Ballard, Martin (ed). New Movement in The Study and Teaching of History, Bloomington \& London: Indiana University Press.

Hasan, S. Hamid. (2012). Pendidikan Sejarah untuk Memperkuat Pendidikan Karakter, in Jurnal Paramita Vol. 2 No. 1 - Januari [ISSN : 0854-0039], pp. 81 - 95.

Heywood, Andrew. (2013). Politik, Yogyakarta : Pustaka Pelajar.

Joebagio, Hermanu. (2015). Eksplorasi Networking Collective Memories dengan Model Pembelajaran Sejarah, in Garvey, Brian., and Krug Mary. Model-Model Pembelajaran Sejarah di Sekolah Menengah, (translated by Dian Faradilla), Yogyakarta : Ombak.

Kartodirdjo, Sartono. (1987). Kebudayaan Pembangunan dalam Perspektif Sejarah, Yogyakarta: Gadjah Mada University Press.

(1992). Pendekatan Ilmu Sosial dalam Metodologi Sejarah, Jakarta: Gramedia Pustaka

Utama. 
(2005). Sejak Indische Sampai Indonesia, Jakarta: Penerbit Buku Kompas.

Kochhar, S.K. (2008). Teaching of History (Pembelajaran Sejarah), Jakarta: Gramedia Widiasarana Indonesia.

Maarif, Ahmad Syafii. (2003). Benedetto Croce (1866-1952) dan Gagasannya tentang Sejarah, Yogyakarta: Suara Muhammadiyah.

Soedjatmoko. (1976). Kesadaran Sejarah dan Pembangunan, in Majalah Prisma No. 7 Th V.

Syam, Nur. (2009). Tantangan Multikulturalisme Indonesia : Dari Radikalisme Menuju Kebangsaan, Yogyakarta: Penerbit Kanisius.

Ujan, Andre Ata, et.al. (2011). Multikulturalisme : Belajar Hidup Bersama dalam Perbedaan, Jakarta : PT. Indeks.

Walsh, W.H. (1960). Philosophy of History : An Introduction, New York : Harper and Row Publishers.

Zuhdi, Susanto. (2014). Nasionalisme, Laut, dan Sejarah, Jakarta : Penerbit Komunitas Bambu.

\section{Copyrights}

Copyright for this article is retained by the author(s), with first publication rights granted to the journal.

This is an open-access article distributed under the terms and conditions of the Creative Commons Attribution license (http://creativecommons.org/licenses/by/4.0/). 